\title{
Dental Status and Prosthetic Rehabilitation in Elderly Population in Relation to Socioeconomic Factors in Republika Srpska
}

\author{
Igor Radović, Lado Davidović, Jelena Krunić, Nikola Stojanović \\ University of East Sarajevo, Faculty of Medicine in Foča, Department of Dental Pathology, Foča, Bosnia and Herzegovina
}

\begin{abstract}
SUMMARY
Introduction The aim of this study was to determine dental status and prosthetic rehabilitation in elderly population in relation to socioeconomic factors in Republika Srpska.

Material and Methods The study included 262 subjects ( 133 males and 129 females) aged 65-74 years. Dental status was assessed using DMFT index and its components ( D - decayed, $M$ - extracted, F - filled tooth) and analysed in relation to socioeconomic factors: gender, level of education and monthly income. Prosthetic restorations were recorded for both jaws in accordance with criteria of the World Health Organisation.

Results The mean DMFT was 27.2. Females had the highest DMFT index score (29.1) while highly educated subjects had the lowest score (22.7). The mean number of missing teeth was 22.7 . There were $28.2 \%$ edentulous respondents. Significant difference in the number of edentulous persons was recorded in relation to gender, education and monthly income. In total, $16.8 \%$ of subjects had functional dentition ( $\geq 20$ natural teeth). $48.5 \%$ and $32.1 \%$ of elderly respondents were found to have at least one form of prosthetic restoration in upper and lower jaw, respectively. Complete dentures were the most common prosthetic restorations.

Conclusion Socioeconomic factors influenced dental status in elderly population. Removable dentures were more common restorations compared to crowns and bridges.

Keywords: dental status; DMFT; edentulous; prosthodontic rehabilitation
\end{abstract}

\section{INTRODUCTION}

Almost all industrialized and developing countries have witnessed demographic evolution characterized by aging population. In 2005, about $16.5 \%$ of the population in 52 European countries was over 65 years old. According to demographic projections by the World Health Organization (WHO) this percentage will increase to $22.4 \%$ by 2025 [1]. With longer life expectancy and increase of elderly population, new problems in their medical, social and dental care are projected. Changes in oral cavity of elderly people are present due to the physiological process of aging as well as chronic and degenerative diseases that they might have. Tooth loss as complication of tooth decay and periodontal disease is the most pronounced whithin this population. Functional consequences of tooth loss, especially posteriors, are reflected in reduced masticatory efficiency, neuromuscular disorders and impaired inter-maxillary relations [2]. If teeth are not replaced this population is facing poorer diet, weight loss and gastrointestinal disturbances.

Epidemiological data in many industrialized European countries as well as in developing countries now show oral health improvement in elderly population, reduction of teeth loss and prevalence of edentulism. Therefore, there is reduced number of indications for complete dentures and increased incidence of fixed restorations $[3,4,5]$. Literature has shown that socioeconomic factors may influence the incidence of tooth loss and prosthetic rehabilitation in elderly population $[6,7,8]$.

The aim of this study was to determine dental status in relation to socio-economic factors (gender, level of education and monthly income) and presence of prosthetic restorations in elderly population in Republika Srpska.

\section{MATERIAL AND METHODS}

The study was conducted in 2011 in five municipalities of Republika Srpska: Foca, East Sarajevo, Gacko and Bijeljina. In each of these municipalities at least 50 subjects aged 65-74 years were examined. Subjects were randomly selected and examinations were done in seniors' associations and individual homes. The final sample consisted of 262 persons (133 male and 129 female).

Dental examinations were performed with the use of artificial light, dental mirror and explorer according to the standards and criteria of the WHO. All teeth were checked including third molars. To assess dental status DMFT index and its components (D - decayed, $\mathrm{M}$ - extracted, F - filled tooth) were used. Extracted teeth included lost teeth for any reason (caries, periodontal disease, trauma, 
Table 1. Mean values of DMFT index and its components in relation to socio-economic characteristics of respondents Tabela 1. Srednje vrednosti indeksa KEP i njegovih komponenata u odnosu na socioekonomske odlike ispitanika

\begin{tabular}{|c|c|c|c|c|c|c|}
\hline \multirow{2}{*}{\multicolumn{2}{|c|}{$\begin{array}{l}\text { Socio-economic characteristics } \\
\text { Socioekonomske odlike }\end{array}$}} & \multirow{2}{*}{$\mathbf{N}$} & \multicolumn{4}{|c|}{$\begin{array}{l}\text { DMFT index } \\
\text { KEP indeks }\end{array}$} \\
\hline & & & $\begin{array}{l}\mathrm{D} \pm \mathrm{SD} \\
\mathrm{K} \pm \mathrm{SD}\end{array}$ & $\begin{array}{c}M \pm S D \\
E \pm S D\end{array}$ & $\begin{array}{l}\mathrm{F} \pm \mathrm{SD} \\
\mathrm{P} \pm \mathrm{SD}\end{array}$ & $\begin{array}{c}\mathrm{DMFT} \pm \mathrm{SD} \\
\mathrm{KEP} \pm \mathrm{SD}\end{array}$ \\
\hline \multicolumn{2}{|l|}{$\begin{array}{l}\text { Total } \\
\text { Ukupno }\end{array}$} & 262 & $1.97 \pm 3.34$ & $22.65 \pm 8.51$ & $2.58 \pm 4.23$ & $27.21 \pm 5.98$ \\
\hline \multirow{3}{*}{$\begin{array}{l}\text { Gender } \\
\text { Pol }\end{array}$} & $\begin{array}{l}\text { Male } \\
\text { Muški }\end{array}$ & 133 & $2.08 \pm 3.09$ & $20.17 \pm 8.89$ & $3.18 \pm 4.79$ & $25.42 \pm 6.89$ \\
\hline & $\begin{array}{l}\text { Female } \\
\text { Ženski }\end{array}$ & 129 & $1.84 \pm 3.60$ & $25.19 \pm 7.29$ & $1.95 \pm 3.48$ & $29.09 \pm 4.14$ \\
\hline & \multicolumn{2}{|l|}{$\mathrm{p}$} & NS & $<0.01$ & NS & $<0.001$ \\
\hline \multirow{4}{*}{$\begin{array}{l}\text { Education } \\
\text { Obrazovanje }\end{array}$} & $\begin{array}{l}\text { Elementary }{ }^{1} \\
\text { Osnovno }^{1}\end{array}$ & 146 & $2.12 \pm 3.82$ & $25.45 \pm 6.97$ & $1.05 \pm 1.95$ & $28.61 \pm 4.89$ \\
\hline & $\begin{array}{l}\text { High school } \\
\text { Srednje }^{2}\end{array}$ & 81 & $1.9 \pm 2.65$ & $20.65 \pm 8.95$ & $3.49 \pm 4.49$ & $26.19 \pm 6.49$ \\
\hline & $\begin{array}{l}\text { Higher }^{3} \\
\text { Visoko }^{3}\end{array}$ & 35 & $1.46 \pm 3.43$ & $15.57 \pm 8.10$ & $6.8 \pm 6.59$ & $23.74 \pm 7.06$ \\
\hline & \multicolumn{2}{|l|}{$\mathrm{p}$} & NS & $\begin{array}{c}<0.01 \\
(1: 2 / 1: 3 / 2: 3) \\
\end{array}$ & $\begin{array}{c}<0.01 \\
(1: 2 / 1: 3 / 2: 3) \\
\end{array}$ & $\begin{array}{c}<0.01 \\
(1: 2 / 1: 3) \\
\end{array}$ \\
\hline \multirow{3}{*}{$\begin{array}{l}\text { Income } \\
\text { Prihodi }\end{array}$} & $0-380 \mathrm{KM}$ & 124 & $2.12 \pm 3.75$ & $24.52 \pm 7.48$ & $1.33 \pm 2.39$ & $27.97 \pm 5.09$ \\
\hline & $\geq 380 \mathrm{KM}$ & 128 & $1.83 \pm 2.93$ & $20.96 \pm 9.04$ & $3.70 \pm 5.10$ & $26.49 \pm 6.48$ \\
\hline & \multicolumn{2}{|l|}{$\mathrm{p}$} & NS & $<0.01$ & $<0.01$ & NS \\
\hline
\end{tabular}

$\mathrm{N}$ - number of respondents; SD - standard deviation; NS - no statistically significant difference

$\mathrm{N}$ - broj ispitanika; SD - standardna devijacija; NS - nema statistički značajne razlike

prosthetic reasons, etc.). Prosthetic rehabilitation was recorded for each jaw separately. The absence or presence and the type of dental restoration without analyzing its adequacy and functionality were recorded.

Dental status and the prevalence of edentulism were analyzed in relation to socio-economic factors: gender, level of education and monthly income. According to the level of education respondents were grouped into three categories: elementary, high school, and university graduates. According to monthly income respondents were divided into two groups. The first group included subjects with a minimum wage $(380 \mathrm{KM})$ or less, while the second group included those with monthly income higher than a minimum wage in Republika Srpska.

Obtained data were analyzed using SPSS 19.0 (SPSS Inc., Chicago IL, USA) for Windows with standard procedures of descriptive and comparative statistics. For descriptive analyzes mean value and standard deviation were determined while for comparative statistics Student's $\mathrm{t}$-test and chi-square test were used. Values of $\mathrm{p}<0.05$ were considered statistically significant.

\section{RESULTS}

The average DMFT index in persons aged 65-74 years was 27.21. The highest percentage was for extracted teeth (84\%) where respondents had the average of 22.7 extracted teeth. The value of DMFT index in males was 25.42 while in females it was 29.09 . In relation to education DMFT value in people with primary education was 28.61; with high school education it was 26.19 whereas it was 23.74 in people with university education. The average DMFT index was 27.97 in those with low monthly income, while in those with higher income it was 26.49 .
There was statistically significant difference in values of DMFT index in relation to gender $(\mathrm{p}<0.0001)$ and years of education $(\mathrm{p}<0.01)$ compared to monthly income where statistically significant difference was not found $(\mathrm{p}>0.05)$. The analysis of DMFT individual components showed no significant difference in the prevalence of dental caries between different groups ( $p>0.05)$. The number of extracted teeth was significantly higher in females compared to males, in patients with primary education and people with lower income $(\mathrm{p}<0.01)$. Most of restored teeth ( $\mathrm{F}$ component) were found in respondents with university degree and those with higher income $(\mathrm{p}<0.01)$ (Table 1).

The percentage of edentulous people in surveyed population was $28.8 \%$. This percentage in females was 36.4 while in males 20.3 . In relation to education $37 \%$ of edentulous respondents had primary education, $22.6 \%$ high school and $5.7 \%$ had university education. In the pool of respondents with lower income $33.1 \%$ were edentulous while this number was $23.9 \%$ for persons with higher income. Statistical analysis showed significant difference in edentulism in relation to gender $(p<0.0001)$, education $(\mathrm{p}<0.01)$ and monthly income $(\mathrm{p}<0.05)$. Number of patients with functional dentition present $(20$ or more teeth) was $16.8 \%$. Males in higher percentage had functional dentition (25.6\%) compared to women (7.8\%). Functional dentition was also found more frequently in persons with higher education (48.6\%) and higher income (22.5\%) (Table 2).

Most respondents did not have any form of dental restoration. $51.5 \%$ of examined population did not have prosthetic restoration in the upper jaw and $67.9 \%$ did not have any restoration in the lower jaw. The most common restoration was denture, $30.9 \%$ in the upper jaw and $17.9 \%$ in the lower jaw. Restorations in both jaws were found in less than $7 \%$ (Table 3). 
Table 2. Distribution of present teeth in relation to socio-economic characteristics of respondents Tabela 2. Raspodela zastupljenih zuba u odnosu na socioekonomske odlike ispitanika

\begin{tabular}{|c|c|c|c|c|c|}
\hline \multirow{2}{*}{\multicolumn{2}{|c|}{$\begin{array}{l}\text { Socio-economic characteristics } \\
\text { Socioekonomske odlike }\end{array}$}} & \multirow{2}{*}{$N$} & \multicolumn{3}{|c|}{$\begin{array}{l}\text { Teeth present } \\
\text { Zastupljeni zubi }\end{array}$} \\
\hline & & & $\begin{array}{c}\text { Edentulous } \\
\text { Bezubost }\end{array}$ & $\begin{array}{l}1-19 \text { teeth } \\
1-19 \text { zuba }\end{array}$ & $\begin{array}{l}\geq 20 \text { teeth } \\
\geq 20 \text { zuba }\end{array}$ \\
\hline \multicolumn{2}{|l|}{$\begin{array}{l}\text { Total } \\
\text { Ukupno }\end{array}$} & 262 & $28.2 \%$ & $55.0 \%$ & $16.8 \%$ \\
\hline \multirow{3}{*}{$\begin{array}{l}\text { Gender } \\
\text { Pol }\end{array}$} & $\begin{array}{l}\text { Male } \\
\text { Muški }\end{array}$ & 133 & $20.3 \%$ & $54.1 \%$ & $25.6 \%$ \\
\hline & $\begin{array}{l}\text { Female } \\
\text { Ženski }\end{array}$ & 129 & $36.4 \%$ & $55.8 \%$ & $7.8 \%$ \\
\hline & \multicolumn{2}{|l|}{$\mathrm{p}$} & $\mathrm{p}<0.0001$ & & \\
\hline \multirow{4}{*}{$\begin{array}{l}\text { Education } \\
\text { Obrazovanje }\end{array}$} & $\begin{array}{l}\text { Elementary }{ }^{1} \\
\text { Osnovno }^{1} \\
\end{array}$ & 146 & $37.0 \%$ & $56.2 \%$ & $6.8 \%$ \\
\hline & $\begin{array}{l}\text { High school }{ }^{2} \\
\text { Srednje }^{2}\end{array}$ & 81 & $22.6 \%$ & $56.8 \%$ & $21.0 \%$ \\
\hline & $\begin{array}{l}\text { Higher }^{3} \\
\text { Visoko }^{3}\end{array}$ & 35 & $5.7 \%$ & $45.7 \%$ & $48.6 \%$ \\
\hline & \multicolumn{2}{|l|}{$\mathrm{p}$} & \multicolumn{3}{|c|}{$\begin{array}{c}\mathrm{p}<0.01(1: 2 / 2: 3) \\
\mathrm{p}<0.0001(1: 3)\end{array}$} \\
\hline \multirow{3}{*}{$\begin{array}{l}\text { Income } \\
\text { Prihodi }\end{array}$} & $0-380 \mathrm{KM}$ & 124 & $33.1 \%$ & $56.5 \%$ & $10.5 \%$ \\
\hline & $\geq 380 \mathrm{KM}$ & 128 & $23.9 \%$ & $53.6 \%$ & $22.5 \%$ \\
\hline & \multicolumn{2}{|l|}{$\mathrm{p}$} & \multicolumn{3}{|c|}{$\mathrm{p}<0.05$} \\
\hline
\end{tabular}

$\mathrm{N}$ - number of respondents

$\mathrm{N}$ - broj ispitanika

\section{DISCUSSION}

This study focused on analysis of dental status and prosthetic rehabilitation in elderly population in Republika Srpska. DMFT index that provides information about the number of carious, extracted and filled teeth was used. Although DMFT does not specify the severity of caries lesion or area affected by decay, it was possible to determine dental status in the study population. The mean value of DMFT index in our study was 27.21. Due to the lack of relevant data and previous studies in the observed age group in Republika Srpska it was difficult to draw conclusions about long-term changes in the prevalence of dental caries. Similar studies in the region showed lower values of DMFT. Bego et al. [9] showed that the value of DMFT index in subjects of the same age in Croatia was 23.72, while in Slovenia it declined from 27 to 22.5 in the period 1987-1999 [10]. Lower values were recorded in western European countries. Schiffner et al. [5] found DMFT value in the same age group of 23.6 in German population, while this value in Austria was 23.3 [11]. Distribution of decayed and filled teeth in the current study was consistent with other studies [12]. Lower values of decayed and filled teeth could be the result of higher number of extracted teeth in the study population. This indicates that extraction is still the most common interventions in this population in Republika Srpska. Lower number of missing teeth was recorded in Hungarian respondents (19), while in Turkey the number of missing teeth in this age population was $24.6[12,13]$.

Results of our study showed that DMFT and E component were significantly higher in females. Similar results were found in studies in Greece and Brazil $[14,15]$. The association between gender and status of teeth was more pronounced in women due to psychosocial compon-
Table 3. Prosthetic restorations in respondents

Tabela 3. Protetički status ispitanika

\begin{tabular}{|l|c|c|c|c|}
\hline \multirow{2}{*}{ Protetički status } & \multicolumn{2}{|c|}{$\begin{array}{c}\text { Upper jaw } \\
\text { Gornja vilica }\end{array}$} & \multicolumn{2}{c|}{$\begin{array}{c}\text { Lower jaw } \\
\text { Donja vilica }\end{array}$} \\
\cline { 2 - 5 } & N & $\%$ & N & $\%$ \\
\hline $\begin{array}{l}\text { No prosthetic restorations } \\
\text { Nema protetički rad }\end{array}$ & 135 & 51.5 & 178 & 67.9 \\
\hline $\begin{array}{l}\text { One fixed prosthetic restoration } \\
\text { Jedan fiksni rad }\end{array}$ & 6 & 2.3 & 5 & 1.9 \\
\hline $\begin{array}{l}>1 \text { fixed prosthetic restoration } \\
>1 \text { fiksni rad }\end{array}$ & 11 & 4.2 & 4 & 1.5 \\
\hline $\begin{array}{l}\text { Partial denture } \\
\text { Parcijalna proteza }\end{array}$ & 22 & 8.4 & 23 & 8.8 \\
\hline $\begin{array}{l}\text { Fixed prosthetic restoration + } \\
\text { partial denture } \\
\text { Fiksni rad + parcijalna proteza }\end{array}$ & 7 & 2.7 & 5 & 1.9 \\
\hline $\begin{array}{l}\text { Complete denture } \\
\text { Totalna proteza }\end{array}$ & 81 & 30.9 & 47 & 17.9 \\
\hline
\end{tabular}

$\mathrm{N}$ - number of respondents

$\mathrm{N}$ - broj ispitanika

ent, hormonal imbalance during pregnancy and menopause and biochemical composition and flow of saliva [16]. Osteoporosis leads to periodontal disease, lower bone density in jaws and consequently teeth loss. Eating disorders accompanied with gastric reflux are more common in older females and also have influence on teeth loss $[16,17]$.

Another our finding was association between higher index value and number of missing teeth and lower education. Similar results were found in other studies [18]. Respondents with university degree had the lowest DMFT index. This could be attributed to the fact that years of education increase awareness of the importance of oral and general health.

In our study, the number of missing teeth was also related to income level; therefore, the value of $\mathrm{E}$ compon- 
ent was significantly higher in respondents with lower income. As restorative treatments require greater number of visits and higher expenses, that could be one reason for frequent teeth extraction in this group. Petersen et al. indicated that number of visits to dentist significantly decreased in persons with lower level of education and low income [7]. Our findings are in agreement with studies from Denmark, Switzerland and Sweden that showed poor economic status correlated with number of missing teeth $[3,7]$.

Edentoulism is good indicator of oral health of the population. Reducing the number of edentulous persons in the population of 35-44 years and 65-74 years is one of the WHO's goals by 2020 [19]. In our study population the number of edentulous patients was $28.2 \%$. A national survey in China showed low rate of edentulism (10.5\%) in the population of 65-74 years old compared to results obtained in Western countries and our study [20]. Similar or slightly higher percentage of edentoulism (32\%) was recorded in Greece in the same age population [14]. Other studies in European countries have shown significant reduction of edentulous people in the age group 65-74 years during the past two decades. Therefore, in Switzerland, the number of edentulous people decreased from $26.8 \%$ to $13.8 \%$ in the $1992-2002$ period, whereas in Germany in the period 1999-2005 this number decreased for $2 \%$ $[3,21]$. In relation to examined variables edentulism is generally more common in women, people with primary education and lower income [14].

Increased prevalence of dental restorations recorded in upper compared to lower jaw indicates more frequent tooth loss in the upper jaw. Higher number of restorations in upper jaw could be also attributed to aesthetic component. Visibility of upper teeth during speaking, eating, laughing could be the reason why respondents had more frequent rehabilitation in the upper jaw. Higher incidence of removable dentures in relation to fixed restorations could be attributed to high E component of DMFT index. Loss of a large number of teeth decreases possibility of fixed prosthetic rehabilitation. Also, dental insurance in Republika Srpska for people older than 65 years financially cover dentures but not fixed restorations.

\section{CONCLUSION}

Elderly people aged 65-74 years in Republika Srpska had high DMFT and high number of extracted teeth. Major impact on teeth loss was found in socioeconomic factors: gender, years of education and level of income. Dentures were the most frequent prosthetic restorations in both jaws.

\section{REFERENCES}

1. Bourgeois D, Berger P, Hescot P, Leclercq MH, Doury J. Oral health status in 65-74 years old adults in France. 1995. Rev Epidemiol Sante Publique. 1999; 47:55-9.

2. Tihaček-Šojić Lj, Stančić I, Jelenković A, Milić-Lemić A. Mogućnost protetske rehabilitacije skraćenog zubnog niza u pacijenata starije dobi. Stomatološki glasnik Srbije. 2008; 55:238-46.

3. Zitzmann NU, Stachelin K, Walls AW, Menghini G, Weiger R, Zemp Stutz E. Changes in oral health over a 10-yr period in Switzerland. Eur J Oral Sci. 2008; 116:52-9.

4. Zitzmann NU, Hagmann E, Weiger R. What is the prevalence of various tzpes of prosthetic dental restorations in Europe? Clin Oral Implants Res. 2007; 18:20S-33S.

5. Schiffner U, Hoffmann T, Kerschbaum T, Micheelis W. Oral health in German children. adolescents, adults and senior citizens in 2005. Community Dent Health. 2009; 26:18-22.

6. Suominen-Taipale AL, Alanen P, Helenius H, Nordblad A, Uutela A. Edentulism among Finnish adults of working age, 1978-1997. Community Dent Oral Epidemiol. 1999; 27:353-65.

7. Petersen PE, Kjoller M, Boge Christensen L, Krustrup U. Changing dentate status of adults. use of dental health services and achievement of national dental health goals in Denmark by the year 2000. J Public Health Dent. 2004; 64:127-35.

8. Musacchio E, Perissinotto E, Binotto P, Sartori L, Silva-Netto F, Zambon $\mathrm{S}$, et al. Tooth loss in the elderly and its association with nutritional status, socioeconomic and life style factors. Acta Odontol Scand. 2007; 65:78-86.

9. Bego K, Njemirovskij V, Pelivan I. Epidemiološko istraživanje oralnog zdravlja u srednjoj Dalmaciji: pilot studija. Acta Stomatol Croat. 2007; 41:337-44.

10. Vrbic V. Reasons for the caries decline in Slovenia. Community Dent Oral Epidemiol. 2000; 28:126-32.

11. Städtler P, Bodenwinkler A, Sax G. Caries prevalence in a 35-44- and 65-74-year-old Austrian population. Caries Res. 2002; 36:207.

12. Madléna $M$, Hermann $P$, Jáhn $M$, Fejérdy P. Caries prevalence and tooth loss in Hungarian adult population: results of a national survey. BMC Public Health. 2008; 8:364.

13. Gökalp S, Guciz Doğan B, Tekçiçek M, Berberoğlu A, Ünlüer Ş. National survey of oral health status of children and adults in Turkey. Community Dental Health. 2010; 27:12-7.

14. Mamai-Homata E, Topitsoglou V, Oulis C, Margaritis V, Polychronopoulou A. Risk indicators of coronal and root caries in Greek middle aged adults and senior citizens. BMC Public Health. 2012; 12:484.

15. Rihs LB, da Silva DD, de Sousa Mda L. Dental caries and tooth loss in adults in a Brazilian Southeastern State. J Appl Oral Sci. 2009; 17:392-6.

16. Berta PC, Staehelin K, Dratva J, Zemp Stutz E. Female gender with dental care and dental hygiene. but not with complete dentition in the Swiss adult population. J Public Health. 2007; 15:361-7.

17. Inagaki K, Noguchi T. Osteoporosis: a risk factor in periodontal disease. Clin Calcium. 2002; 12:978-86.

18. Skudutyte R, Aleksejuniene J, Eriksen HM. Dental caries in adult Lithuanians. Acta Odont Scand. 2000; 58:143-7.

19. Hobdell M, Petersen PE, Clarkson J, Johnson N. Global goals for oral health 2020. Int Dent J. 2003; 53:285-8.

20. Hong-Ying W, Petersen PE, Jin-You B, Bo-Xue Z. The second national survey of oral health status of children and adults in China. Int Dent J. 2002; 52:283-90.

21. Müller F, Naharro M, Carlsson GE. What are the prevalence and incidence of tooth loss in the adult and elderly population in Europe. Clin Oral Impl Res. 2007; 18:2-14. 


\title{
Stanje zuba u odnosu na socioekonomske faktore i protetički status kod osoba starije životne dobi u Republici Srpskoj
}

\author{
Igor Radović, Lado Davidović, Jelena Krunić, Nikola Stojanović \\ Univerzitet u Istočnom Sarajevu, Medicinski fakultet u Foči, Katedra za dentalnu patologiju, Foča, Bosna i Hercegovina
}

\begin{abstract}
KRATAK SADRŽAJ
Uvod Cilj ovog istraživanja bio je da se odrede stanje zuba u odnosu na socioekonomske faktore i protetički status kod starih ljudi u Republici Srpskoj.

Materijal i metode rada U istraživanje su uključene 262 osobe (133 muškarca i 129 žena) starosti $65-74$ godine. Stanje zuba je određeno primenom indeksa KEP i njegovih komponenata ( $\mathrm{K}$ - karijes; $\mathrm{E}$ - ekstrahovan zub; $\mathrm{P}$ - plombiran zub) i analizirano $u$ odnosu na socioekonomske faktore: pol, godine obrazovanja i mesečne prihode ispitanika. Protetički status je procenjen za svaku vilicu posebno prema kriterijumima Svetske zdravstvene organizacije.

Rezultati Srednja vrednost indeksa KEP u ispitivanoj populaciji bila je 27,21. Najveća vrednost ovog indeksa zabeležena je kod osoba ženskog pola $(29,09)$, dok je najniža vrednost zabeležena kod ispitanika s visokom stručnom spremom $(23,74)$. Ispitanici su u proseku imali 22,7 ekstrahovanih zuba. Bezubost u ispitivanoj populaciji bila je $28,2 \%$. Značajna razlika u broju ispitanika bez zuba zabeležena je u odnosu na pol, godine obrazovanja i mesečne prihode. Funkcionalna denticija ( 20 i više zuba) ustanovljena je kod $16,8 \%$ ispitanika. Prisustvo bar jednog oblika zubne nadoknade zabeleženo je kod $48,5 \%$ ispitanika u gornjoj vilici, odnosno kod $32,1 \%$ ispitanika u donjoj vilici. Totalna proteza je bila najčešća zubna nadoknada.

Zaključak Socioekonomski faktori imaju veliki uticaj na stanje zuba kod osoba starije životne dobi. Mobilne nadoknade su zabeležene u obe vilice u poređenju s fiksnim nadoknadama.

Ključne reči: stanje zuba; KEP indeks; bezubost; protetička rehabilitacija
\end{abstract}

\section{UVOD}

Skoro sve razvijene zemlje, kao i zemlje u razvoju, svedoci su demografske evolucije koja se odlikuje starenjem stanovništva. Osobe starije od 65 godina činile su 2005. godine oko 16,5\% stanovništva u 52 evropske zemlje. Prema demografskim projekcijama Svetske zdravstvene organizacije, taj procenat će porasti na $22,4 \%$ do 2025. godine [1]. S produženjem ljudskog veka i povećanjem udela starijeg stanovništva u ukupnoj populaciji, nameću se i novi problemi njihovog medicinskog, socijalnog i stomatološkog zbrinjavanja. Do promena u usnoj duplji starih osoba dolazi usled starenja kao fiziološkog procesa, ali i brojnih hroničnih i degenerativnih oboljenja. Gubitak zuba kao komplikacija karijesa i parodontopatija najizraženiji je upravo kod ovih ljudi. Funkcionalne posledice gubitka zuba, naročito bočnih, ogledaju se u redukovanoj mastikatornoj efikasnosti, poremećajima neuromuskularnih kretnji i međuviličnih odnosa [2]. Ukoliko nije praćen zamenom odgovarajućim zubnim nadoknadama, gubitak zuba dovodi do slabijeg kvaliteta ishrane, gubitka telesne težine i gastrointestinalnih smetnji.

Podaci epidemioloških studija u mnogim evropskim zemljama pokazuju poboljšanje stanja oralnog zdravlja osoba starije životne dobi koje se odlikuje smanjenjem gubitka zuba i smanjenjem prevalencije bezubosti. Stoga je i smanjen broj indikacija za totalne proteze, a povećana učestalost fiksnih nadoknada $[3,4,5]$. Veliki broj autora navodi da socioekonomski faktori mogu uticati na gubitak zuba i stepen protetičke rehabilitacije kod ove populacije $[6,7,8]$.

Uzimajući u obzir navedene činjenice, cilj ovog istraživanja bio je da se utvrde stanje zuba u odnosu na socioekonomske faktore (pol, nivo obrazovanja i visina mesečnih primanja) i protetički status kod starih osoba u Republici Srpskoj.

\section{MATERIJAL I METODE RADA}

Istraživanje je urađeno tokom 2011. godine u pet opština Republike Srpske: Foča, Istočno Sarajevo, Nevesinje, Gacko i Bijeljina. U svakoj od navedenih opština pregledano je najmanje 50 ispitanika starosti 65-74 godine. Pregledi ispitanika obavljeni su metodom slučajnog izbora u udruženjima penzionera i u domaćinstvima. Konačan uzorak činile su 262 osobe (133 muškarca i 129 žena).

Stomatološki pregledi vršeni su uz primenu veštačkog osvetljenja, stomatološkog ogledalceta i stomatološke sonde prema standardima i kriterijumima Svetske zdravstvene organizacije. Određeno je stanje svih zuba, uključujući i treće molare. Stanje zuba i broj izgubljenih zuba određeni su primenom indeksa KEP i njegovih komponenata ( $\mathrm{K}$ - karijes; E - ekstrahovan zub; $\mathrm{P}$ - plombiran zub). Kao ekstrahovani zubi u ovom istraživanju označeni su zubi koji su izvađeni usled bilo kojeg razloga (karijes, parodontopatija, povreda, protetički razlozi itd.). Protetički status zabeležen je za svaku vilicu posebno. Utvrđeni su izostanak ili postojanje i tip zubne nadoknade bez analize njihove adekvatnosti i funkcionalnosti.

Stanje zuba i prevalencija bezubosti analizirani su u odnosu na socioekonomske faktore: pol, nivo obrazovanja i mesečne prihode ispitanika. Prema nivou obrazovanja ispitanici su grupisani u tri kategorije: sa osnovnom školom, srednjom i višom, odnosno visokom stručnom spremom. Prema mesečnim prihodima ispitanici su svrstani u dve grupe: prvu su činili oni s jednom minimalnom platom (380 konvertibilnih maraka) i manje, dok su u drugoj grupi bile osobe čija su mesečna primanja veća od jedne minimalne plate u Republici Srpskoj.

Svi podaci analizirani su i obrađeni u statističkom programu SPSS 19.0 (SPSS, Inc., Chicago, IL, USA) za Windows standardnim postupcima deskriptivne i komparativne statistike. U okviru deskriptivne analize određivane su srednja vrednost i 
standardna devijacija, dok su u okviru komparativne statistike za ocenu značajnosti između izdvojenih grupa korišćeni Studentov t-test i $\chi^{2}$-test. Vrednosti p manje od 0,05 smatrane su statistički značajnim u svim analizama.

\section{REZULTATI}

Prosečna vrednost indeksa KEP kod ispitanika bila je 27,21. U strukturi KEP najveći udeo činili su ekstrahovani zubi (84\%), a ispitanici su u proseku imali 22,7 izgubljenih zuba. Vrednost indeksa KEP kod muškaraca bila je 25,42, a kod žena 29,09. U odnosu na godine obrazovanja, zabeležene vrednosti indeksa KEP bile su 28,61 kod osoba sa osnovnim obrazovanjem, 26,19 kod osoba sa srednjim obrazovanjem, odnosno 23,74 kod osoba sa višom/visokom stručnom spremom. U odnosu na prihode, vrednost ispitivanog indeksa bila je 27,97 kod osoba s malim mesečnim primanjima, a 26,49 kod ispitanika s većim primanjima. Obradom dobijenih podataka uočena je statistički značajna razlika u vrednostima indeksa KEP u odnosu na pol $(\mathrm{p}<0,0001)$ i godine obrazovanja $(\mathrm{p}<0,01)$, dok u odnosu na mesečne prihode nije bilo statistički značajne razlike između dve posmatrane grupe ispitanika ( $p>0,05)$. Analizom pojedinačnih komponenata indeksa KEP uočeno je da između ispitivanih grupa nije bilo značajne razlike u rasprostranjenosti karijesa ( $p>0,05)$. Broj ekstrahovanih zuba bio je značajno veći kod žena, ispitanika $s$ osnovnim obrazovanjem i osoba s malim primanjima $(\mathrm{p}<0,01)$. Najviše saniranih zuba (komponenta $\mathrm{P}$ ) imali su ispitanici s višom/visokom stručnom spremom i osobe s mesečnim primanjima većim od $380 \mathrm{KM}$ ( $\mathrm{p}<0,01)$. Podaci su dati u tabeli 1 .

Učestalost totalne bezubosti kod pregledanih ispitanika bila je $28,8 \%$. Zube nije imalo $36,4 \%$ žena i $20,3 \%$ muškaraca. U odnosu na godine obrazovanja, bez zuba je bilo $37,0 \%$ ispitanika s osnovnim obrazovanjem, $22,6 \%$ sa srednjim i $5,7 \%$ sa višim/ visokim obrazovanjem. Posmatrano u odnosu na prihode, bez zuba je bilo $33,1 \%$ ispitanika s prihodima nižim od $380 \mathrm{KM}$ i $23,9 \%$ ispitanika s višim mesečnim primanjima. Statistička obrada podataka pokazala je da postoji statistički značajna razlika $\mathrm{u}$ pogledu bezubosti u odnosu na pol $(\mathrm{p}<0,0001)$, nivo obrazovanja $(\mathrm{p}<0,01)$ i mesečne prihode $(\mathrm{p}<0,05)$. Udeo ispitanika $s$ funkcionalnom denticijom u ispitivanoj populaciji (20 i više zuba) bio je 16,8\%. Muškarci su u većem procentu imali funkcionalnu denticiju $(25,6 \%)$ u odnosu na žene $(7,8 \%)$. U pogledu stepena obrazovanja, funkcionalna denticija je bila najveća kod osoba s višim/visokim obrazovanjem (48,6\%), dok je u odnosu na prihode funkcionalna denticija bila češća kod osoba sa većim prihodima (22,5\%). Podaci su dati u tabeli 2.

Najveći broj ispitanika nije imao nijedan oblik zubne nadoknade. Tako u gornjoj vilici 51,5\% pregledanih osoba nije imalo protetički rad, odnosno 67,9\% ispitanika u donjoj vilici. Kod ispitanika koji su imali neki oblik zubne nadoknade najčešća je bila totalna proteza, s učestalošću od 30,9\% u gornjoj, odnosno $17,9 \%$ u donjoj vilici. Učestalost fiksnih radova u obe vilice bila je manja od 7\% (Tabela 3).

\section{DISKUSIJA}

Istraživanje prikazuje kakvi su stanje zuba i stepen protetičke rehabilitacije kod dela stanovnika starije životne dobi u Repu- blici Srpskoj. Za procenu stanja zuba korišćen je indeks KEP, koji daje informacije o broju karijesnih, ekstrahovanih i plombiranih zuba. Iako navedeni indeks ne precizira uznapredovalost karijesne lezije, niti površine zahvaćene karijesom, analizom dobijenih podataka moguće je utvrditi stanje zuba u ispitivanoj populaciji. Srednja vrednost indeksa KEP u ovom istraživanju bila je 27,21. Zbog nedostatka relevantnih podataka i studija za ispitivanu starosnu grupu na prostorima Republike Srpske, teško je doneti zaključak o dugoročnim promenama u prevalenciji karijesa. Rezultati studija iz regiona pokazuju niže vrednosti ispitivanog indeksa. Istraživanje Bega (Bego) i saradnika [9] pokazalo je da je vrednost indeksa KEP kod ispitanika starih 65-74 godine u Hrvatskoj 23,72, dok je u Sloveniji zabeleženo smanjenje vrednosti sa 27 na 22,5 u periodu 1987-1999. godine kod ispitanika iste starosne dobi [10]. Niže vrednosti zabeležene su i u zapadnoevropskim zemljama. Šifner (Schiffner) i saradnici [5] su utvrdili vrednost indeksa od 23,6 u istoj starosnoj grupi među nemačkom populacijom, dok je kod austrijskih ispitanika vrednost indeksa KEP bila 23,3 [11]. Rasprostranjenost karijesnih i plombiranih zuba u našem istraživanju nije bila velika i u skladu je s rezultatima drugih studija [12] . Niže vrednosti bi mogle biti rezultat udela većeg broja ekstrahovanih zuba u ispitivanoj populaciji. Ispitanicima je u proseku nedostajalo 22,7 zuba, što ukazuje na činjenicu da je vađenje i dalje najčešća intervencija kod ove populacije u Republici Srpskoj. Manje vrednosti nedostajućih zuba zabeležene su kod mađarskih ispitanika (19), dok je u turskoj populaciji vrednost bila nešto veća u odnosu naše rezultate $(24,6)[12,13]$.

Rezultati našeg istraživanja su takođe pokazali da su vrednosti indeksa KEP i komponente E značajno veće kod žena. Slični rezultati zabeleženi su i u studijama u Grčkoj i Brazilu $[14,15]$. Veza između pola i stanja zuba mogla bi se objasniti činjenicama da su kod žena izraženiji psihosocijalna komponenta, hormonski disbalans tokom trudnoće i menopauze, biohemijski sastav i protok pljuvačke [16]. Osteoporoza, koja dovodi do oboljenja parodoncijuma, smanjenja gustine vilične kosti, a samim tim i do gubitka zuba, zatim poremećaji ishrane praćeni refluksom želudačnog sadržaja i izloženost zuba delovanju hlorovodonične kiseline takođe su izraženiji kod žena starije životne dobi $[16,17]$.

Analiza rezultata našeg istraživanja pokazala je da su veće vrednosti indeksa i broja zuba koji nedostaju zabeleženi kod ispitanika s osnovnim obrazovanjem. Slični rezultati dobijeni su i u drugim istraživanjima [18]. Ispitanici sa višom/visokom stručnom spremom imali su najmanje vrednosti indeksa KEP. Ovaj podatak mogao bi se pripisati činjenici da godine obrazovanja imaju veliki uticaj na svest o značaju zdravlja zuba, kako za oralno, tako i za opšte zdravlje.

U našem istraživanju broj nedostajućih zuba bio je povezan i sa visinom primanja, pa su vrednost komponente E bile značajno veće kod osoba s malim primanjima u Republici Srpskoj. Restaurativni tretmani zahtevaju veći broj poseta, a samim tim i veće troškove stomatološke zaštite, što bi mogao biti jedan od razloga češćeg vađenja zuba u ovoj grupi ispitanika. U svom radu Petersen (Petersen) i saradnici [7] navode da se broj poseta stomatologu značajno smanjuje kod osoba s nižim stepenom obrazovanja i malim primanjima. Naši nalazi su u saglasnosti s rezultatima nekoliko studija iz Danske, Švajcarske i Švedske u kojima je pokazano da je loš ekonomski status u korelaciji sa brojem zuba koji nedostaju [3,7]. 
Nivo bezubosti je dobar indikator oralnog zdravlja stanovništva. Smanjenje broja osoba bez zuba starosti 35-44 godine i 65-74 godine jedan je od ciljeva Svetske zdravstvene organizacije koji treba dostići do 2020. godine [19]. Naše istraživanje je pokazalo da je udeo osoba bez zuba u ispitivanoj populaciji $28,2 \%$. Nacionalno istraživanje u Kini pokazalo je izuzetno nisku stopu bezubosti $(10,5 \%)$ među stanovništvom starosti 65-74 godine u odnosu na rezultate dobijene u zapadnim zemljama i našem istraživanju [20]. Nešto veći procenat bezubosti (32\%) zabeležen je kod grčkih ispitanika istog životnog doba [14]. Brojne prospektivne studije u evropskim zemljama pokazuju znatno smanjenje broja osoba bez zuba u starosnoj grupi 65-74 godine u protekle dve decenije. Tako je u Švajcarskoj broj osoba bez zuba smanjen sa $26,8 \%$ na $13,8 \%$ u periodu 1992-2002, dok je u Nemačkoj u periodu 1999-2005. godine bezubost kod ispitanika starih 65-74 godine smanjena za $2 \%$ $[3,21]$. U odnosu na ispitivane varijable, bezubost je češća kod žena, osoba s osnovnom stručnom spremom i malim prihodima [14].

Veća učestalost zubnih nadoknada je zabeležena u gornjoj vilici u odnosu na donju, što pokazuje da su gubitak zuba i bezubost češći u gornjoj vilici. Veći broj nadoknada u gornjoj vilici mogao bi se pripisati i estetskoj komponenti. Činjenica je da je vidljivost gornjih zuba pri svakodnevnim radnjama orofacijalnog sistema (govor, ishrana, smejanje) veća u odnosu na donje zube, pa je moguće da ispitanici prednost daju protetičkoj rehabilitaciji gornje vilice. Veća učestalost mobilnih nadoknada u odnosu na fiksne mogla bi se pripisati i visokoj vrednosti komponente E indeksa KEP. Naime, usled gubitka velikog broja zuba nije bilo moguće obaviti protetičku rehabilitaciju fiksnim radom, već su postavljane indikacije za mobilne nadoknade. Uticaj bi mogla imati i zakonska regulativa usluga koje pokriva obavezno zdravstveno osiguranje. Inače, u Republici Srpskoj lica starija od 65 godina imaju pravo na besplatnu mobilnu nadoknadu, dok troškove izrade fiksnih i kombinovanih protetičkih radova snosi pojedinac.

\section{ZAKLJUČAK}

Rezultati istraživanja pokazuju da osobe starosti $65-74$ godine $\mathrm{u}$ Republici Srpskoj imaju visoke vrednosti indeksa KEP i visoku stopu ekstrahovanih zuba. Na gubitak zuba veoma utiču socioekonomski faktori, kao što su pol, godine obrazovanja i lični prihodi. U strukturi protetičkih radova znatno je veća učestalost mobilnih protetičkih nadoknada $u$ obe vilice. 